\title{
RESEARCH ONTHE EFFECT OF SPORTS ON STUDENTS'PHYSICAL FITNESS UNDER THE HEALTH INTERVENTION POLICY
}

\author{
PESQUISA SOBRE O EFEITO DOS ESPORTES NA APTIDÃO FISICA DOS ALUNOS DEACORDO COM A \\ POLITICA DE INTERVENÇÃOEMSAÚDE
}

Original Article

ARTIGO ORIGINAL

Artículo Original

\author{
INVESTIGACIÓN SOBRE EL EFECTO DE LOS DEPORTES EN LA APTITUD FÍSICA DE LOS ESTUDIANTES EN \\ EL MARCO DE LA POLITICA DE INTERVENCIÓN SANITARIA
}

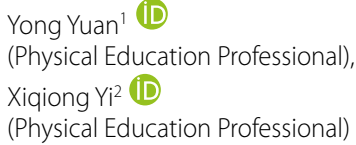

1. Department of Physical Education, Dongguan Polytechnic, Dongguan, China.

2. Department of Art and Design, Dongguan Polytechnic, Dongguan, China.

\section{Correspondence:}

Xiqiong Yi

Dongguan Polytechnic, Dongguan, China.

YIXIQIONG@126.com.

\begin{abstract}
Introduction: The main reason for the decline in college students' physical fitness and health is the lack of physical exercise, the emphasis on study and the neglect of physical exercise, and the lowering of the physical fitness requirements of college students. Objective: The paper analyzes the status quo and existing problems of college students' physical fitness and proposes that the school party committee issues policy-based health intervention measures, encourages school physical education teachers to participate in students' after-school physical exercises, and extensively develops school mass sports activities. Methods: The paper uses a literature method, questionnaire survey, comprehensive evaluation method, etc., to analyze the internal and external factors of college students' physical decline. Results: Through the practice density test of students in physical education teaching, it is learned that physical education in the first grade can fully develop students' physical fitness, and the practice density of each class reaches $60 \%$. The practice density of the second-grade optional courses is about $20 \%$, and it cannot achieve the purpose of effective physical exercise. Conclusions: The current teaching content and teaching methods of physical education classes cannot effectively complete physical education tasks. It is necessary to adjust the teaching content further and improve the teaching methods. Level of evidence Il; Therapeutic studies - investigation of treatment results.
\end{abstract}

Keywords: Students; Exercise; Health intervention measures.

\section{RESUMO}

Introdução: O principal motivo do declínio da condição física e da saúde dos estudantes universitários é a falta de exercícios físicos, a negligência dos exercícios físicos devido à ênfase no estudo e a redução das exigências de aptidão física dos estudantes universitários. Objetivo: O documento analisa o status quo e os problemas existentes de aptidão física de estudantes universitários e propõe que o comitê do partido escolar emita medidas de intervenção de saúde baseadas em políticas, encoraje os professores de educação física a participarem extensivamente dos exercícios físicos dos alunos após as aulas. Métodos: O artigo utiliza um questionário e um método de avaliação abrangente, etc., para analisar os fatores internos e externos de deterioração física dos estudantes universitários. Resultados: Por meio do teste de densidade de prática dos alunos no ensino de educação física, aprende-se que a educação física na primeira série pode desenvolver plenamente a aptidão física dos alunos, sendo que a prática de cada aula chega a $60 \%$. A prática do curso eletivo de segundo grau é de aproximadamente $20 \%$ e não pode atingir o objetivo de exercícios físicos eficazes. Conclusões: O conteúdo e os métodos de ensino atuais das aulas de educação física não podem completar as tarefas de educação física com eficácia. É necessário aperfeiçoar ainda mais o conteúdo de ensino e melhorar os métodos de ensino. Nível de evidência Il; Estudos terapêuticos: investigação dos resultados do tratamento.

Descritores: Estudantes; Exercício físico; Medidas de intervenção em saúde.

\section{RESUMEN}

Introducción: La principal razón del declive en la condición física y la salud de los estudiantes universitarios es la falta de ejercicio físico, el descuido del ejercicio físico por el énfasis en el estudio, y la reducción de los requisitos de aptitud física de los estudiantes universitarios. Objetivo: El documento analiza el status quo y los problemas existentes de la aptitud física de los estudiantes universitarios y propone que el comité del partido escolar emita medidas de intervención de salud basadas en políticas, aliente a los maestros de educación física de la escuela a participar en los ejercicios físicos de los estudiantes después de la escuela de manera extensiva. Métodos: El artículo utiliza cuestionario y método de evaluación integral, etc., para analizar los factores internos y externos del deterioro físico de los estudiantes universitarios. Resultados: A través de la prueba de densidad de práctica de los estudiantes en la enseñanza de educación física, se aprende que la educación física en el primer grado puede desarrollar plenamente la aptitud física de los estudiantes, y la práctica de cada clase alcanza el 60\%. La práctica de los cursos optativos de segundo grado es de aproximadamente el 20\% y no puede lograr el propósito de un 
ejercicio físico efectivo. Conclusiones: El contenido y los métodos de enseñanza actuales de las clases de educación física no pueden completar eficazmente las tareas de educación física. Es necesario ajustar aún más el contenido de la enseñanza y mejorar los métodos de enseñanza. Nivel de evidencia ll; Estudios terapéuticos: investigación de los resultados del tratamiento.

Descriptores: Estudiantes; Ejercicio físico; Medidas de intervención sanitaria.

\section{INTRODUCTION}

The main reason for the decline of college students' physical fitness and health is the lack of physical exercise, the emphasis on study and the neglect of physical exercise, and the lowering of college students' physical fitness requirements. To change this situation, it is necessary to deepen the reform of physical education in colleges and universities, strengthen the construction of physical education courses, carry out extracurricular sports activities in an all-round way, improve college students' awareness of sports health, and further improve the physical education curriculum evaluation system, so that students can develop well through physical education courses.' Physical exercise habits can effectively enhance physical fitness and improve health.

\section{METHOD}

\section{Research objects}

There are 928 college students, including 183 boys and 745 girls.

\section{Research methods}

1. We use modern information technology to extensively collect and consult the research literature on college students' physical status at home and abroad and reform the college physical education curriculum. 2. Based on Chinese economic system, the status quo of college students'physical fitness and college physical education curriculum reform, practical measures and methods are proposed by investigating and analyzing colleges and universities. 3. We use divergent and innovative thinking methods and methods to conduct questionnaire surveys and interviews with college teachers and college students, collect relevant first-hand information and data, and organically integrate theory with practice, literature and data.

\section{Statistical methods of attribute weights}

The attribute weight determination can be divided into subjective weighting method, objective weighting method, and subjective and objective weight combination weighting method. The entropy method is a classic method for calculating objective weights. According to the information theory principal entropy, if the information entropy of a specific attribute index is smaller, the amount of information provided is more. The role it can play in decision-making is also more significant. ${ }^{2}$ Larger, so its weight is greater; on the contrary, the greater the information entropy of an indicator, the smaller its weight. The entropy method process is as follows: first, calculate the entropy $\boldsymbol{e}_{j}$ of each attribute and the attribute difference coefficient $g_{j}$. The calculation formula for the entropy value and the different degree is as follows:

$$
e_{j}=-\frac{1}{\operatorname{Inm}} \sum_{j=1}^{m} p_{i j} \operatorname{In} p_{i j}
$$

$$
p_{i j}=b_{i j} / \sum_{i=1}^{n} b_{i j}
$$

$$
g_{j}=1-e_{j}
$$

The larger $g_{i}$ is, the more critical the corresponding attribute is. The objective weight of the attribute is:

$$
w_{j}^{o}=\frac{g_{j}}{\sum_{i=1}^{m} g_{j}}=\frac{1-e_{j}}{m-\sum_{j=1}^{m} e_{j}}
$$

For the convenience of calculation, the subjective linguistic weight can be converted into an interval number $\left[w^{L}, W^{U}\right]$, and then converted into an exact number. ${ }^{3}$ According to formula (5), the subjective linguistic weight is converted to the real number subjective weight.

$$
W_{j}^{s}=\frac{u_{j}+I_{j}\left(u_{j} / u_{j}+v_{j}\right)}{\sum_{j=1}^{m}\left(u_{j}+I_{j}\left(u_{j} / u_{j}+v_{j}\right)\right)}
$$

$u=w^{L}, V=1-w^{U}, I=w^{U}-w^{L}$. The combined weight should be as close as possible to the subjective and objective weights. To ensure that the difference between the combined weight $W_{j}$ and the subjective weight $W_{j}^{s}$ and the objective weight $W_{j}^{o}$ is as small as possible, the following combination weight objective optimization model can be established based on the principle of minimum discriminative information:

$$
\min F=\sum_{j=1}^{m} w_{j} \operatorname{In} \frac{w_{j}}{w_{j}^{o}}+\sum_{i=1}^{m} w_{j} \operatorname{In} \frac{w_{j}}{w_{j}^{s}}
$$

$$
\text { s.t. } \sum_{j=1}^{n} w_{j}=1 ; w_{j}>0
$$

We use the LaGrange multiplier method to solve the minimum value of the above function to get the combined weight value ${ }^{4}$.

$$
w_{j}=\frac{\sqrt{w_{j}^{o} \sqsubset w_{j}^{s}}}{\sum_{i=1}^{m} \sqrt{w_{j}^{o}\left\lceil w_{j}^{s}\right.}}
$$

Determine the positive ideal plan and the negative ideal plan. By attribute weight $w_{j}$. Multiply the normalized attribute $b_{i j}$ to form a weighted normalized matrix T:

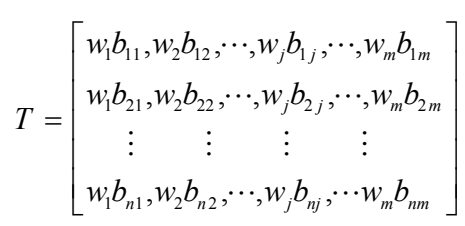


The maximum value of each column in the matrix is selected to form a positive and negative ideal solution, where the maximum value is $y_{j}^{+}$. And the minimum value $y_{j}^{-}$is as formula (10).

$$
\left\{\begin{array}{l}
y_{j}^{+}=\max \left(w_{j} b_{i j}\right) \\
y_{j}^{-}=\min \left(w_{j} b_{i j}\right)
\end{array} i \in[1, n], j \in[1, m]\right.
$$

We calculate the Euclidean distance between each decision plan and the positive ideal plan and the negative ideal plan. The distances between the decision plan and the positive ideal plan and the negative ideal plan are formulas (11) and (12), respectively:

$$
d_{i}^{+}=\sqrt{\sum_{j=1}^{m}\left(w_{j} b_{i j}-y_{j}^{+}\right)^{2}}
$$

$$
d_{i}^{-}=\sqrt{\sum_{j=1}^{m}\left(w_{j} b_{i j}-y_{j}^{-}\right)^{2}}
$$

Calculate each plan's proximity and the positive and negative ideal plan according to the proximity calculation formula. ${ }^{5}$ The proximity calculation formula is as follows:

$$
\xi=\frac{d_{i}^{+}}{d_{i}^{+}+d_{i}^{-}}
$$

We then sort by proximity. The greater the proximity, the better the solution.

\section{RESULTS}

\section{Research on the current physical condition of college students}

Table 1 takes the results of the physique testing statistics of college students from 2008 to 2018 to illustrate the trend of college students' physique.

The comparative analysis shows that: (1) The Queenlet Index shows an upward development trend for boys and a downward-rising-downward development trend for girls. This phenomenon may be related to college

Table 1. List of Comprehensive Evaluation of College Students' Physical Fitness.

\begin{tabular}{c|c|c|c|c|c}
\hline Gender & Weight coefficient & 2008 score & 2015 score & 2018 score & $\begin{array}{c}\text { Evaluation } \\
\text { results }\end{array}$ \\
\hline \multirow{4}{*}{ Male } & $\begin{array}{c}\text { Weight/ } \\
\text { Height } \times 1000\end{array}$ & 16.4 & 17.82 & 19.4 & rise \\
\cline { 2 - 6 } & $\begin{array}{c}\text { Vital capacity/ } \\
\text { weight }\end{array}$ & 13.2 & 10.42 & 9.88 & decline \\
\cline { 2 - 6 } & 50m & 11.37 & 11.02 & 9.99 & decline \\
\cline { 2 - 6 } & Standing long jump & 12.08 & 12.05 & 10.12 & decline \\
\cline { 2 - 6 } & Pull ups & 11.34 & 11.8 & 9.2 & decline \\
\cline { 2 - 6 } & $1000 \mathrm{~m}$ & 10.14 & 8.75 & 7.35 & decline \\
\cline { 2 - 6 } & Total fitness score & 74.53 & 71.86 & 66.02 & decline \\
\hline \multirow{4}{*}{ Female } & $\begin{array}{c}\text { Weight/ } \\
\text { Height } \times 1000\end{array}$ & 16.31 & 17.19 & 15.8 & decline \\
\cline { 2 - 6 } & $\begin{array}{c}\text { Vital capacity/ } \\
\text { weight }\end{array}$ & 14.32 & 11.81 & 11.3 & decline \\
\cline { 2 - 6 } & S0m & 12.03 & 11.56 & 10.8 & decline \\
\cline { 2 - 6 } & Standing long jump & 12.27 & 11.75 & 10.66 & decline \\
\cline { 2 - 6 } & Pull ups & 9.34 & 9.35 & 9 & decline \\
\cline { 2 - 6 } & $800 m$ & 11.19 & 10.12 & 9.8 & decline \\
\cline { 2 - 6 } & Total fitness score & 75.46 & 71.78 & 67.36 & decline \\
\hline
\end{tabular}

students'emphasis on body type. Queenlet Index evaluates the level of physical development and symmetry, which can reflect the fullness (tissue density) and the human body's nutritional status. It has typical significance for the evaluation of physical fitness. (2) The vital capacity index shows a downward trend. A vital capacity index is a useful indicator reflecting the human body's functional capacity, and it is an essential aspect of measuring physical fitness. It proves that lack of physical exercise is the main reason for the decline of students' cardiopulmonary function. (3) Speed quality shows a downward trend. Speed quality is an essential physical quality that people often need in life and sports activities. (4) Standing long jump shows a downward trend. It shows that the student's lower limbs have insufficient explosive power. (5) Arm muscle strength (boys pull-ups) and abdominal muscle strength (girls sit-ups) showed an overall downward trend. (6) Endurance $(1000 \mathrm{~m}$ for boys and $800 \mathrm{~m}$ for girls), the overall trend is decreasing.

\section{ANALYSIS OF TEST RESULTS OF PHYSICAL HEALTH STANDARDS}

\section{Evaluation and analysis of height and weight}

Students' height and weight did not change much after one year of enrollment, and the number of malnourished students increased after two years of enrollment. Among them, the proportion of undernourished male students increased from $2.32 \%$ to $5.29 \%$, the proportion of lower-weight students decreased from $32.66 \%$ to $4.22 \%$, and the proportion of normal-weight students decreased from $35.44 \%$ to $30.99 \%$. The number of overweight and obese students did not change much. The proportion of undernourished female students increased from $4.22 \%$ to 11.35. The proportion of lower-weight students increased from $39.16 \%$ to $43.83 \%$, and the number of normal-weight, overweight, and obese students decreased to varying degrees. ${ }^{6}$ (Table 2 ) The survey results show that: weight loss is related to female students'results using various methods to lose weight.

\section{Comparative analysis of vital capacity scores}

The 2010 test results are higher than the 2008 test results. Among them, boys' outstanding achievement rate increased from $16.11 \%$ to $24.98 \%$, and the failure rate decreased from $18.40 \%$ to $11.04 \%$; the outstanding rate of girls increased from $20.61 \%$ to $31.27 \%$, and the failure rate decreased from $3.58 \%$ to $1.91 \%$. The 2018 test results are lower than the 2010 test results. Among them, boys' outstanding achievement rate decreased from $24.98 \%$ to $18.30 \%$, and the failure rate increased from $11.04 \%$ to $15.15 \%$; the outstanding rate of girls decreased from $31.27 \%$ to $22.50 \%$, and the failure rate increased from $1.91 \%$ to $3.86 \%$. (Table 3 )

\section{Comparative analysis of step test results}

The primary test of the step test is used to determine the function of the cardiovascular system. It can also be indirectly inferred that the

Table 2. Comparison of height and weight (\%).

\begin{tabular}{c|c|c|c|c}
\hline \multicolumn{2}{c|}{ Test year } & $\mathbf{2 0 0 8}$ & $\mathbf{2 0 1 0}$ & $\mathbf{2 0 1 8}$ \\
\hline \multirow{2}{*}{ Malnutrition } & male & 2.52 & 2.32 & 5.29 \\
\cline { 2 - 5 } & Female & 4.11 & 4.22 & 11.53 \\
\hline \multirow{2}{*}{ Lower weight } & male & 31.76 & 32.66 & 4.22 \\
\cline { 2 - 5 } & Female & 38.06 & 39.16 & 43.83 \\
\hline \multirow{2}{*}{ Normal weight } & male & 35.83 & 35.44 & 30.99 \\
\cline { 2 - 5 } & Female & 46.34 & 45.31 & 36.83 \\
\hline \multirow{2}{*}{ Overweight } & male & 7.39 & 7.28 & 7.19 \\
\cline { 2 - 5 } & Female & 5.43 & 4.65 & 2.64 \\
\hline \multirow{2}{*}{ Obesity } & male & 22.5 & 22.3 & 22.15 \\
\cline { 2 - 5 } & Female & 6.06 & 6.66 & 4.53 \\
\hline
\end{tabular}


results of the endurance test in 2010 are better than those in 2008. Among them, the boys' excellent rate increased from 30.7\% to 49.46\%, and the failure rate decreased; the excellent rate of girls increased from $31.34 \%$ to $42.16 \%$, and the failure rate was zero. The 2018 test results are lower than the 2010 test results. Among them, the excellent rate of boys decreased from $49.46 \%$ to $42.56 \%$, the excellent rate decreased from $38.19 \%$ to $30.99 \%$, and the failure rate increased; the excellent rate of girls decreased from $42.16 \%$ to $40.96 \%$, and the excellent rate decreased from $45.15 \%$ to $39.85 . \%$. (Table 4 )

Table 3. Vital Capacity Score Comparison Table (\%).

\begin{tabular}{c|c|c|c|c}
\hline \multicolumn{2}{c|}{ Test year } & $\mathbf{2 0 0 8}$ & $\mathbf{2 0 1 0}$ & $\mathbf{2 0 1 8}$ \\
\hline \multirow{3}{*}{ Malnutrition } & male & 16.11 & 24.98 & 18.3 \\
\cline { 2 - 5 } & Female & 20.61 & 31.27 & 22.5 \\
\hline \multirow{2}{*}{ Lower weight } & male & 35 & 37.59 & 36.15 \\
\cline { 2 - 5 } & Female & 45.21 & 43.66 & 45.3 \\
\hline \multirow{2}{*}{ Normal weight } & male & 30.5 & 26.39 & 30.4 \\
\cline { 2 - 5 } & Female & 30.6 & 23.16 & 28.37 \\
\hline \multirow{2}{*}{ Overweight } & male & 18.4 & 11.04 & 15.15 \\
\cline { 2 - 5 } & Female & 3.58 & 1.91 & 3.86 \\
\hline \multirow{2}{*}{ Obesity } & male & 16.11 & 24.98 & 18.3 \\
\cline { 2 - 5 } & Female & 20.61 & 31.27 & 22.5 \\
\hline
\end{tabular}

Table 4. Step comparison table (\%).

\begin{tabular}{c|c|c|c|c}
\hline \multicolumn{2}{c|}{ Test year } & $\mathbf{2 0 0 8}$ & $\mathbf{2 0 1 0}$ & $\mathbf{2 0 1 8}$ \\
\hline \multirow{2}{*}{ Malnutrition } & male & 30.7 & 49.46 & 42.56 \\
\cline { 2 - 5 } & Female & 31.34 & 42.16 & 40.96 \\
\hline \multirow{2}{*}{ Lower weight } & male & 48.29 & 38.19 & 30.99 \\
\cline { 2 - 5 } & Female & 51.44 & 45.15 & 39.85 \\
\hline \multirow{2}{*}{ Normal weight } & male & 19.38 & 11.68 & 21.98 \\
\cline { 2 - 5 } & Female & 7.22 & 12.69 & 19.19 \\
\hline \multirow{2}{*}{ Overweight } & male & 1.63 & 0.66 & 4.47 \\
\cline { 2 - 5 } & Female & 0 & 0 & 0 \\
\hline \multirow{2}{*}{ Obesity } & male & 30.7 & 49.46 & 42.56 \\
\cline { 2 - 5 } & Female & 31.34 & 42.16 & 40.96 \\
\hline
\end{tabular}

\section{DISCUSSION}

\section{Internal and external factors for the decline of college stu- dents' physical fitness}

The decline of college students' physical fitness is undoubtedly the most important reason. At present, the decline in the physical fitness of primary and middle school students with the majority of only children hinders the improvement of college students' overall physical fitness. Still, the main reason is that many college students usually ignore physical exercise, and non-intellectual factors have not received due attention. Students emphasize learning and exercise, neglecting physical education teaching, extracurricular sports activities are left unattended, students do not have the concept of exercise in their hearts, and under the background that the society generally ignores students' physical fitness, it is even more difficult for college students to decline their physical fitness. Attract enough attention. The physical health of college students is on the decline.

\section{Investigation of college students' participation in extracur- ricular physical exercises}

The proportion of people who participate in extracurricular physical exercises 1-2 times a week (over 30 minutes each time) accounts for 37.6\% of the total; occasionally participates, and the time is variable accounted for 34.3\%; more than three times a week (over 30 minutes each time) accounted for $25.6 \%$. Only $3.4 \%$ did not participate in extracurricular exercises, which shows that students are willing to participate in extracurricular physical exercises as long as they provide conditions and correct guidance. It can also be seen from the table that participation in extracurricular physical exercises is better in the lower grades than in the upper grades. The first and second grades accounted for $30.1 \%$ and $25 \%$ more than three times a week; the third and fourth grades accounted for $16.3 \%$ and $18.1 \%$, one week. -2 The first and second grades accounted for $40.5 \%$ and $37 \%$; the third and fourth grades accounted for $33.2 \%$ and $28.1 \%$; occasional participation, the time is variable, the third and fourth grades are higher than the first and second grades, and the third and fourth grades respectively account for 38\% and $41.1 \%$; the first and second grades accounted for $27.1 \%$ and $31.7 \%$, respectively; the number of non-exercise participants is more than that of the third and fourth grades than the first and second grades. The third and fourth grades are $4.6 \%$ and $5.7 \%$, respectively, the first and second grades are $1.48 \%$ and $2.3 \%$. With the increase of grades, the proportion of not participating in extracurricular physical exercises increases, which has a lot to do with not offering physical education classes in senior grades.

\section{CONCLUSION}

The current teaching content and teaching methods of physical education classes cannot effectively complete physical education tasks. It is necessary to adjust the teaching content further and improve the teaching methods. In response to students' physical health problems, it is recommended that the school party committee introduce policy interventions to encourage students to exercise for one hour a day and establish a long-term mechanism.

All authors declare no potential conflict of interest related to this article

AUTHORS' CONTRIBUTIONS: Each author made significant individual contributions to this manuscript. Yong Yuan: writing and performing surgeries; Xiqiong Yi: data analysis and performing surgeries, article review and intellectual concept of the article.

\section{REFERENCES}

1. Imas YV, Dutchak MV, Andrieieva OV, Kashuba VO, Kensytska IL, Sadovskyi O. O. Modern approaches to the problem of values' formation of students' healthy lifestyle in the course of physical training. Phys Educ Stud. 2018;22(4):182-9.

2. Kim I, Ward P, Sinelnikov O, Ko B, Iserbyt P, Li W, et al. The influence of content knowledge on pedagogical content knowledge: An evidence-based practice for physical education. Journal of Teaching in Physical Education. 2018;37(2): 133-43.

3. Harvey SP, Lambourne K, Greene JL, Gibson CA, Lee J, Donnelly JE. The effects of physical activity on learning behaviors in elementary school children: A randomized controlled trial. Contemporary School Psychology. 2018;22(3):303-12.
4. Gu X, Chen YL, Jackson AW, Zhang T. Impact of a pedometer-based goal-setting intervention on children's motivation, motor competence, and physical activity in physical education. Phys Educ Sport Pedagogy. 2018;23(1):54-65.

5. van de Kop JH, van Kernebeek WG, Otten RH, Toussaint HM, Verhoeff AP. School-based physical activity interventions in prevocational adolescents: a systematic review and meta-analyses. Journal of Adolescent Health. 2019;65(2):185-94.

6. Braun SS, Roeser RW, Mashburn AJ, Skinner E. Middle school teachers' mindfulness, occupational health and well-being, and the quality of teacher-student interactions. Mindfulness. 2019;10(2):245-55 